\title{
Reproduction of Communicative Negativity Through Instrumental Irrationality
}

\author{
Ugur Baloglu \\ Istanbul Gelisim University (Turkey)
}

This paper aims to use Turkey as an example of how the erosion occurring in social communication practices is reproduced in the era of paradoxical experiences, particularly in global crisis environments where risk intensity increases. Recently, 'the great incarceration' situation around the world has forced people to receive news and connect to them via digital platforms. The isolation of social relations for an indefinite period, especially in risk society, causes people to feel constantly under pressure from an unforeseen/indeterminate threat. The increase in the level of anxiety of the individual under pressure, internalizing fear after a while, turns him/herself into the very mechanism that produces anxiety and fear. This mechanism causes society to become paralyzed as a result of increased information pollution and the amount of information during global crisis periods. The paper examines how the negativity in communication has been exploited through the media with crises in different institutional areas -political, economic, and social-recently, in the framework of the terms of risk and trust used by Giddens and Beck's risk society theory. From this point on, the paper focuses on the consequences of the mutual relationship between global crisis, fear culture and the new modern period.

Keywords: COVID-19, global crisis, infodemic, risk society, sociology of communication, media.

\section{W} hen writing 1984, George Orwell thought that people would live under pressure in an absolute surveillance society, depriving them of information; Aldous Huxley, on the other hand, thought that those would be pacified in a "trivial culture" in which they have been living in an illusion that they believe to be free (Postman, 2005: 19).

Both authors seem to be right from today's perspective. The space we live today transforms a global piece of land where the truth is hidden by not hiding from us, and the culture is under pressure without pressure. Today's world is 
increasingly giving a more hopeless image in the perspective of the real social world. The era of paradoxical experiences, which terms as Ulrich Beck's reflexivity modernity (1986), Lyotard's postmodernity (1979), and Giddens' late modernity (1990), forces to change the paradigm of communication, one of the most fundamental elements of life. Our habits, modes of life, lifestyles, the perception of the world, from past to present are being reshaped by unforeseen external factors. As theorists like Beck, Lyotard, Giddens, Harvey, Bauman pointed out, modernity is a concept that cannot be evaluated on a rigid ground. The discourses of modernity based on bourgeois morality that making the instrumentalization of the reason, in today's world, absorb and irreversibly transform all around it, as like a maelstrom that Marshall Berman (1988) said. On the other hand, it tries to integrate the industrial society's habits into a new discourse of modernity.

The COVID-19 pandemic, which has been influencing all over the world in recent days, takes us to a sharp point of separation between the past and the present. Disorders in the institutional dimensions of modernity complicate to take precautions against COVID-19 due to its unpredictable nature. As Beck emphasized (Beck, 2005: 40-41), since having an attitude against global risks with the control and security mechanisms in the industrial society, the global change in the phenomenon of risk has the phenomenon of danger infiltrates to all the capillaries of real social life. This situation may cause individuals to become hyper-individualized in social communication practices and even to self-isolation. The self-isolation of pragmatist individual who benefiting from the comfort of digital communication platforms, although protecting her/himself from external dangers, affects her/him negatively in a psychological context. In this paper, I try to examine some fractures in communication processes with virtual social life of homo-economicus who is struggling to survive by isolating her/himself. In doing so, I discuss unprecedented ${ }^{1}$ agendas in the country from April 12 to May 5 the highest number of active cases per day in Turkey. ${ }^{2}$ The infodemic that occurred with an excessive amount of information through the media has caused the spread of a culture of fear in terms of health, economic and psychological parallel to the increasing level of anxiety of the society in the risk environment within pandemic period. In this specific culture of fear fed by the risk atmo-

1 Hate speech in Turkey generally emerged on nationalism, ethnic identity, sexual orientation, and it is reproduced on nationalism generally over Kurds, Armenians and Greeks. Besides, the Chinese are not common enemy of Turkish. Secondly, ageism in Turkey is not a very common issue. In the early stages of the outbreak, the sharing of news on social media such as the inability of the elderly to comply with the social distance caused the elderly to be considered as the people who spread the outbreak, not the individuals who should be protected from the outbreak. The government then imposed a curfew on individuals over the age of 65 . Such a prohibition has experienced for the first time in Turkey's history.

2 For the number of activecases, please following thelinks: $<$ https://covid19.saglik.gov.tr $>$; $<$ https://www.worldometers.info/coronavirus/country/turkey>. 
sphere, the people or groups that prevent the solution of problems or create the problems are desired to annihilate. In this regard, there is a significant parallelism between the scapegoating of older people who do not comply with the statement of the Ministry of Health in the first week of COVID-19 and the discourses against Chinese and China, where the virus first appeared. Both of them were exposed to negative discourses due to the information pollution caused by the climate of fear derived from the uncertainty of the risk environment. I will try to identify that the rise in the level of social anxiety lead to the individual towards irrationality as a result of hyper-rationalization and structured the communication practices on the being-negative by examining the reflexes of individuals on digital platforms within the political and economic framework of Turkey, where the pandemic is one of the most severe experienced in the world.

\section{SELF-QUARANTINE}

Michel Foucault states that the great incarceration has an economic and political dimension, both fulfilling the functions of overcoming the economic crisis of the West and making social discipline controllable without pressure. In this period when the police state incarcerates elderly, disabled, mentally ill and unemployed people without discrimination out-of-norm individuals are objectified for the functioning of the developing capitalist economic system by evolving into norm(al) individuals by means of institutions where disciplinary techniques were developed (Foucault, 2011: 106). The production of obedient bodies through oppression in the archaic surveillance society, although it is an inefficient and uneconomic, is the primary means of social control. Thus, the legitimate basis of controlling the unemployment and idleness in the economic crisis is prepared. In this context, in order to understand today's unstable modernity in a Foucauldian perspective, it is necessary to scrutinize at the new forms of subjectivity of people, since it can be said that the behavioral and intellectual practices of individuals are re-structured in the digital truth cosmos. It is seen that social life has begun to converge the real and virtual world, just as the rapid digitalization of economic capital, to avoid the unpredictable risk factor created by the pandemic. Therefore, even in developing countries such as Turkey, ${ }^{3}$ social

3 The difference from Western societies of Turkey is due to the simultaneous experience to East and West. For this reason, Turkey is also different from other Islamic countries. The works written on the modernization of Turkey help us understand the status of it (Ahmad, 1993; Shaw and Shaw, 1977; Ahiska, 2003). The research conducted on the use of digital news source and the awareness of COVID-19 shows that the whole community is aware of the coronavirus. $78 \%$ of citizens think that there is a serious danger to the world. On the other hand, this ratio is lower for Turkey. Slightly more than half the population (55\%) says that the virus poses a serious threat to Turkey. Concerning the coronavirus, $88 \%$ of the public opinion cites news programs on television as a news source. $63 \%$ follow the issue on Social Media. Please see the following link: $<$ https:// 
media sharing of individuals who interact with digital media almost every day becomes important.

Christian Fuchs, researching the effects of digital medium over social life, emphasizes that by the relationship between the internet technology and society turns to multi-dimensional antagonistic structure, differently than being one-dimensional structure in the conventional media (Fuchs, 2008: 240, 345). The antagonistic frame causes spreading cybercrime and cyberhate, decreasing of quality in opposite to the increasing of the quantity of information, electronic surveillance, digital exclusion, on the other hand it enables cyberprotest — "social movements can use the Internet for coordinating and communicating protest or for protesting online" -, online public sphere, overcoming social distance, economic growth, a more participatory democracy (Fuchs, 2008: 248). On the ground of these dual contradictions, it is accurate to say that digital media tools have made a revolution which is alike the effect of nineteenth century photography and fourteenth century press had over the society and culture - "the shift of all of our culture to computer-mediated forms of production, distribution and communication" (Manovich, 2002: 43) - . In the new media culture users can save the media contents, comment on them and put them on the run again. In this regard, the digital technologies create new communication styles and a new culture depending on software, informatics and algorithms. Although it is being said that the new communication technologies gives the chance to reach more information and freedom; it is the social network which decides what to be seen on the news feed by using the algorithms. Therefore, is it possible for the people who post and reach to the news on social media to enlarge their worldview? The social media applications that create virtual community in which the posts of the people who have interests and values like each other are kept together in echo chambers, filters the information. In this new communication medium in which "the I paradigm" is affirmed, it creates more fragmental, polarized and intolerant society regarding Cass Sunstein (2007).

However, with campaigns with \#stayathome hashtag all over the world, it is a mistake to directly evaluate as a social control the fact that an individual who is oppressed under political and social domination is forced or willingly incarcerate her/himself home. On the other hand, populist statements by Donald Trump or Boris Johnson on the COVID-19 pandemic show that if the risk factor of global crisis is neglected, it can lead to nonrecoverable destruction. In the meantime, Boris Johnson's statement from his Twitter account on March 27th shows that COVID-19 is not about class: "Over the last 24 hours I have developed mild symptoms and tested positive for coronavirus. I am now self-isolating, but I will continue to lead the government's response via video-conference as we fight this virus". ${ }^{4}$ At this point, considering Judith Butler's (2020) warning sheds light on our understanding of the negative-based behavior of the individual hyper-ra-

www.ipsos.com/tr-tr/koronavirus-turkiye-toplumunda-nasil-bir-etki-yaratti>.

$4<$ https://twitter.com/BorisJohnson/status/1243496858095411200>. 
tional in the times of global crisis: "Social and economic inequality will make sure that the virus discriminates. The virus alone does not discriminate, but we humans surely do, formed and animated as we are by the interlocking powers of nationalism, racism, xenophobia, and capitalism".

The basic process of communication is defined as sending information from source to receiver through a channel. With the developing technology, anyone who has a social media account and nickname has been in the position of contributing to the sharing of information. The communication process, which is proceeded by private persons - not anyone- through a single channel in traditional media, is deadlock because of the fact that it is tangled up an unlimited source of information today. Excessive information sharing changes the paradigm of communication by destroying the value of information. Increasing information bombardment in a medium ${ }^{5}$ where an average of 9000 tweets per second, both leads to infodemic, eliminating the quality of the information and precludes to reach truth in information pollution. Individuals who desire to be noticed and appreciated in virtual social life through identities ${ }^{6}$ hidden behind a certain avatar, especially, increase the level of anxiety and fear of the society by distorting the facts instead of reaching the common good through the accurate information. It is also related to the recent post-truth discussions and political populism that manipulates of people's choice by instrumentalizing fear. Political populism, ${ }^{7}$ which also carried out on COVID-19 today, ignores the social consequences of noncontrollable risk. This shows that the far-right powers in the world ignore COVID-19 and do not confirm its reality (Zizek, 2020). Similarly, dissident groups seeing the pandemic and its derivative risk factors in the risk society directly as a social constructor or a new maneuver of global capitalist discourse may lead to the spread of conspiracy theories in society. In this context, discussions on the causality of the risks overlook the social consequences that may occur and lead individuals to be irrational in the measures taken for the pandemic. The reaction of the public in the curfew on April 11 and 12 in some cities of Turkey confirms this. The main reasons why people run at the markets,

$5<$ <https://www.internetlivestats.com/one-second/\#tweets-band>.

6 Here is no mention of a sharp distinction between online and offline identities. The spread of the internet creates an environment where people's the physical and the digital, the real and the virtual interaction is more hybrid. Moreover, online and offline identities, boundaries in social, cultural, political, and economic domains can become ambiguous. The point here is that those who produce online texts have the potential to reach an infinite number of people, unlike traditional texts.

7 "COVID-19 Experiences and International Cooperation in the Fight against the Pandemic" video conference was organized on April 8, 2020 with the ambassadors of Rome, Seoul and Beijing, the countries most affected by the epidemic. (Please see the following link: <https:// www.youtube.com/watch?v=5ec6oUzeE4s $>$ ). When the notes of the meeting are analyzed, the frequency of populist discourse such as "PKK terrorist organization", "July 15 resistance", "spirit of National Struggle" and "leadership of our President" is noteworthy. 
disobeying the rule of social isolation, and tending to buy materials that do not need, whether trying to be explained with the Nudge theory ${ }^{8}$ or discussing over the inability to know what to do with the wave of panic, are their distrust of the political power and their future anxiety. These reveals social irrationality and the mental state, which is Giddens' inability to the psychological need fulfillment of human and "the existential anxiety" that he describes as the antithesis of trust in the late modern period (Giddens, 1990: 99-100). Nonetheless, after the exponential growth rate of the spread of COVID-19 in Turkey, it can be said that the economic and social measures to have to be taken are insufficient, especially in the context of the working class. In this context, it can be claimed that COVID-19 can be effective in two different points for lower- and middle-class individuals. The self-isolation of the individual upon the call of the government to the \#stayathome is a type of action that seems unlikely within this period for working-class and refugees who are considered invisible class. For this reason, COVID-19 appears to be a class problem, in which national identity begins to rise again. ${ }^{9}$ In the transition process to digital technology, leaving aside humanist feelings and sacrificing the weakest can be understood as the rational move of the state authority during the crisis. Forcing social life to be isolated without state guarantee mostly increases the social insecurity of the lower class (Butler, 2020). ${ }^{10}$ However, the fear of losing their job of the fragile new middle-class in

8 The Nudge Theory is based on the idea that one option may affect the likelihood of being selected by individuals over another. It is more generally implemented to affect behavior (Thaler and Sunstein, 2009).

9 Although it is said that the global crisis in risk societies will influence people on a non-discriminatory basis in the world by crossing the boundaries, it can be understood more clearly that not the virus discriminates, as Butler said, done by human with the decisions taken by the government. As Beck pointed out, do not discriminate between wealth and the poor or national borders. Chernobyl disaster reality for Beck emphasizes the end of the boundaries between the privileged and non-privileged, but what Beck overlook is that the risk intensity is not the same for every class. Even if the risk exceeds all social and economic distinctions today, with the resolution passed by the government, the poor continue to indirectly protect the wealthy with their own bodies. Briefly, "the precarities engendered by the deepening social inequalities of the neoliberal economic order are likely to intensify the suffering that an outbreak brings" (Leach et al., 2020).

10 Although Beck states (1986: 37) "contained within the globalization and yet clearly differentiated from it is a distribution pattern of risks which contains a considerable amount of political explosive. Sooner or later the risks also catch up with those who produce or profit from them. Risks display a social boomerang effect in their diffusion: even the rich and powerful are not safe from them", this is not the case within the scope of the measures taken by the state authority against COVID-19. Although there seem to be disturbing developments for capital owners such as the economic crisis and stock crashing, the first to be sacrificed in today's economic system are the invisible and unrepresented classes, and then the lower-class individuals whose work are expected to be done by digital automation in the future. Social media posts 
the economic crisis environment oppresses on the individual more than environment of danger of COVID-19. There is a significant parallel between the change of the economy paradigm in the world after 1980 and the employment of middle-class employees in the service sector. The professional middle-class experiences a perpetual "fear of falling" (Ehrenreich, 1989) as it steps into an increasingly uncertain world, separates from other wage-labourers through expertise, and expertise is not a transferable phenomenon. ${ }^{11}$ Jock Young (2007), in his analysis of today's global capitalist system, states that in the late modern period, wage labor has gradually impoverished the middle-class and their anxieties are increasing day by day. Following neoliberal policies, the consumption-indexed lifestyles and getting into debt continuously, especially in global crisis environments, has increased anxiety levels.

The results of COVID-19 Public Opinion Research made in Turkey in the near past supports this. It, is conducted after the first case diagnosis, defines the worried of COVID-19 ones 63\%, while worried of losing the jobs ones $68 \% .{ }^{12}$ This case shows that the economical crisis Turkey faces directly effects the apprehension of future of the people by the decisions made by the political authority. Yet in the modern societies of today, the risks appear not by the outcoming dangers but by the decisions made inside. In this regard, the socio-psychological effect of the global crisis we live in shows that the risk is not personal action and it affects wide masses of people. Today, having no economic security of the skilled labour, which the liberal theorists state as the middle class, emerges in a global crisis environment. For this reason, it can be more easily understood that the positive-based was trivialized in society, since people have been conditioned on the negative-based with the uncertainty of the risk and the concern of when to take control.

\section{UPTICK IN HATE SPEECH}

The fact that COVID-19 from South Asia to Europe is fatal regardless of age under certain conditions what makes people nervous. Infected and death reports

of rich celebrities or the minority enriched by the transfer of property by inheritance clearly reveal the class dimension of global crisis previously mentioned. Please following the link for some posts, <https://www.instagram.com/p/B9_1Ky8gI_Y>; <https://www.instagram.com/p/BAVaVHj8bo>.

11 For more detailed information: Günal, 2013.

12 The research was made to observe the change in perception one week after the Coronavirus Agenda Research conducted to measure the perception of COVID-19 between March 12 14 -after the announcement of the first case in Turkey-. It was conducted by phone call with population over the age of 18 in 12 provinces representing the city across Turkey as the target group of the research. For the details of the research, please follow the link: https://stratejico. com/koronavirus-gundem-arastirmasi-2 
released by the Ministry of Health in Turkey and discussed every day on social media cause people in social isolation to be afraid. Sometimes it increases the hostile attacks on some issues in social media. Especially after the information of pandemic has spread from China started to circulate in the media, heavy insults against Chinese citizens occurred, sharing disturbing content, and increasing racist and nationalist rhetoric are spreading in a crisis environment.

Social distancing and self-quarantine measures of the political authority in Turkey divert people to the internet as a source of socialization. However, instead of using the internet as a social network, it has turned into a tool where conspiracy theories, racist discourses and misinformation are produced. Researches on the rise of misinformation and hate speech on social media after COVID-19 also show the tendency (Schild et al., 2020; Cinelli et al., 2020; Kouzy et al., 2020; Singh et al., 2020). The common results of the researches is the increase in the hate speech towards the Chinese people by generalizing in the social media information pollution because the virus is generally believed to be caused by food consumption in China, personal hygiene. A wave of Sinophobia is increasing day by day in Turkey as well as similar examples all over the world. For example, the Bat soup video ${ }^{13}$ shot in Palau in 2016 is one of the first steps in the wave of hate against the Chinese people on YouTube and Twitter after the COVID-19 outbreak. ${ }^{14}$

Hate speech - even though it is seen as a mental relaxation against the groups and individuals shown target over the linguistic practices- is the starting point of the process leading through hate crimes. The discourses are based on language practical and reproduced to have the mental control over the society. In this regard, it plays a central role in the formation and change of ideologies (Dijk, 1990: 177). The hate speech as an expression of intolerance suppresses the democratic living rights of the individual by pacifizing target individuals or groups in the society. It is clearly stated in the recommendation of European Council Ministries Community (1997) as "any action or language likely to strengthen fears and tensions between groups from different racial, ethnic, national, religious or social background". In this respect, hate speech is a form of intolerant expression that can be described as nationalist, ethnocentric, and discriminatory, based on racist hatred and xenophobia (Weber, 2009). In times of crisis, a crime is needed to relieve the anger and / or energy that accumulates in an environment where social insecurity creates fear. The most comfortable and easiest tool for judging this crime is the internet network, where information sharing can spread rapidly.

$13<\mathrm{https}$ //www.youtube.com/watch?v=3UdKuiTBNq8>. There is also a lot of misinformation on Twitter with the \#yarasacorbası, \#batsoup.

14 However, China ranks 35th in the world in food safety. Turkey seems to be the 41st on the list. Please following the link: <https://teyit.fra1.cdn.digitaloceanspaces.com/wp-content/uploads/2020/02/Global-Food-Security-Index-2019-report-1.pdf $>$. However, hate speech is not only based on the eating and drinking practices of the Chinese people, but also through nationalist, racist discourses with hashtags such as \#WuhanCoronavirus, \# Do $\square$ utürkistan, \# uygurtürk. 
The internet network gives people the opportunity to express, especially through feelings and beliefs, what they cannot say in real social life, and to express what they cannot express. Social media, on the other hand, to people whom they do not know, never see, and no empathy with, allows to attack beliefs, ethnicities, and nations. In times of global crisis such as COVID-19 outbreak, there is a positive correlation especially between misinformation and information overload circulation and when people need the accurate information most, conspiracy theories are produced and fake news begins to increase. Since when objective facts are replaced by personal interpretations based on emotion and belief, the social environment is filled with bias and hate speech. At this point, it should not be forgotten that hate speech triggers a culture of fear, since as Furedi stated, "fears about the future are linked to anxieties about problems today. And, if the future is feared, then reaction to risk is more likely to emphasize the probability of adverse outcomes. As a result, the very meaning of risk is shaped by how society regards its ability to manage change and deal with the future" (Furedi, 2002: 18). The era of post-truth paradoxes that we are in urges the people to believe in populist politics and not to believe in the statements by official institutions. Distrust of rational politics and scientific institutions -those who think that institutions like World Health Organization (WHO) are also cooperating in the global capitalist discourse with the power elite- leads individuals to pursue and support claims close to their worldview.

One of the reasons that communication is negatively charged in times of crisis is the sharpening of the opposition of I and the other. There are ideological patterns of discourses in traditional and social media. In this context, the way the discourse is conveyed and the words used become important, because the provocative use of differences as a derogatory factor increases the distinction between I and the Other (Dijk, 1988). This sharp distinction between East-West cultures results in the virus being attributed to the East, and involves not just China, but culture and nations unlike the West. The media's, especially the private media, motivation to make profit instrumentalize hate speech by causing it to become a medium that reproduces conflicts and crises. This cannot be limited to attacks on Chinese citizens within the framework of the COVID-19 outbreak, otherwise the lynching of citizens who consciously or unconsciously violate the curfew is legitimized. ${ }^{15}$ Similarly, the globalization of the crisis progresses in par-

15 Please following the link: <https://www.hurriyet.com.tr/gundem/kucukcekmecede-hareketli-dakikalar-41492276>. It is noteworthy that the news is on social media in a short time and the posts about the affirmation of violence on various platforms. Almost all of the entries on the title "the final face of those who attacked the police in Küçükçekmece" in Eksisozluk, one of the most visited sites in Turkey, written in hate speech. For example, "The final face of bastards that attacked the police in Küçükçekmece district at noon today", "I think it is not enough... I wish their mouths and noses were displaced and they were not recognized", "These are very beautiful images, there is no problem, but I think the punishment for resistance to the police needs to be increased, then these son of b..s ???? consider ten times while resisting the police". Please following 
allel with the re-rise of nationalism. In this sense, I and the other opposition are structured within the framework of national sentiments and even aid to other countries is criticized. Racist and aggressive comments ${ }^{16}$ against Armenia's request ${ }^{17}$ for medical assistance from Turkey indicates that the problem is not purely China-related.

\section{PRANK OR EXCLUSION?}

Social exclusion has multiple and ambiguous definitions when it examined in the field of communication sociology. In her theoretical work Social exclusion and social solidarity: Three paradigms, Hilary Silver describes social exclusion as "is so evocative, ambiguous, multidimensional, and elastic that it can be defined in many different ways" (Silver, 1994: 536). In COVID-19 quarantine days when communication practices are compelled to change, such ambiguities are linked to economic and social variables that directly affect human psychology.

As the capacity of new communication technologies to reach an unlimited number of people gives the individual a chance to increase their social and economic capital, especially the young generation unconsciously turns to communicative negativity. In other words, new generation individuals who are not very aware of global risk environments and use mass media by placing entertainment in a supra-ideological context transform their social behavior into an exclusivist, discriminatory form. The phenomenon of social exclusion, which is generally described as a problem that exists all over the world, is a problem also that existed but not prevalent before COVID-19 in Turkey. ${ }^{18}$ Analysing Turkey's conventional structure, it is a socially accepted behaviour to respect the old people's lives. Until the 1980's the majority of the population in Turkey lived in the villages where the rate of literacy was low and the age was more prestigious than the authority. ${ }^{19}$ The

the link: <https://eksisozluk.com/kucukcekmecede-polise-saldiranlarin-son-hali--6468367>.

$16<$ https://eksisozluk.com/ermenistanin-turkiyeden-tibbi-yardim-istemesi--6468696>. With the hashtag \#ermenistanayardımyok (nohelptoarmenia), the society is manipulated with inaccurate information, photos and videos and therewith hate speech is tried to be legitimized.

$17<$ https://www.dailysabah.com/politics/diplomacy/armenia-israel-requested-covid19-assistance-from-turkey-presidential-aide-says $>$. In the following days, Armenian foreign ministry spokesperson Anna Naghdalyan announced that there was no such a request. Please following the link: <https://armenpress.am/eng/news/1012024.html>.

18 A research conducted in 2012 in the west of Turkey, "14.2\% of elderly aged 65 years and older were identified as possible victims of abuse" (Ergin et al., 2012: 42).

19 Paul Stirling's research shows that there was great respect for age in all situations of daily life in the 1950s. It is observed that the same etiquette is preserved even if the person is poor (1953: 31).

Please follow the link for the urban and rural population change between 1920-2000 in Turkey, <http://www.tuik.gov.tr/PreIstatistikTablo.do?istab_id=202>. 
starting of disappearing of the conventional life after the globalisation discourses had affected the social communication practices too. Even though the essay in 2012 shows a small example of it, the fact that today over-65 years old individuals were turned into the amusement objects by using the social media as a tool shows that the social exclusion is directly instrumentalized. This digital communication medium in which 'the I paradigm' is affirmed enables the spreading of the negative communication practices fast as the antagonistic frame Fuchs pointed out. Also these behaviour practices supports the idea that in the new media culture, the individuals encouraged by the media holdings induces sharing the images, ideas and statements in the multimedia channels (Jenkins, 2003: 280).

In Turkey, under the measures taken for the COVID-19 outbreak, curfew was imposed on individuals aged 65 who are in the risk group. The introduction of the ban for this age group forced the elder, a fragile group, to compulsory social exclusion by the state authority. Resistance of the elder against the ban and defying the ban, firstly, has been the subject of entertainment on social media platforms with various caps and caused them to be identified as outbreak spreaders. Caps have been replaced by short videos for fun in time and attitude towards the elder has turned into bullying. The transformation of social exclusion imposed to individuals over the age of 65 into hate speech embodies its traditional and modern dichotomy. The new form of social exclusion, which is a result of the desire of older individuals to continue their traditional lifestyles with the new modern individual's desire to become a trend, can cause major problems, especially in times of global crisis. The new generation behavior which is interpreted by Axel Honneth as the desire of the individual to realize himself in modern societies causes the individual to become isolated from the society and create social discontent, rather than self-improvement (Honneth, 2004). At this point, qualitative studies to understand the forms of violence perpetrated through new communication technologies enlighten about the causes of social exclusion practices such as ageism (Patton, 2014). The effort of the new generation, born into social media culture, to prove itself has shifted to virtual social life rather than real social life. The interactive nature and ever-expanding structure of social media make it imperative to change the way people communicate. Attracting attention and reaching more people in the medium that changes, develops and grows every year, moreover, changing direction the economy towards digital medium and expecting more clicks causes new generation individuals to become more brutal and thoughtless individuals, just like the wild face of capitalism. The most important point of such behavior is that it has turned into a global type of action. "A prank has formed one of the major contents of social media landscape purposively designed to draw public attention to perpetrators' walls and to generate comments in a social media driven economy of pay-per-click/view" (Jarrar et al., 2020: 2). In this context, the intergenerational paradigmatic change of communication in global crisis environments can be understood from the actions that the new generation, which perceives each person as a social media object, gradually transforms the distinction between real life and digital life into a simulation universe.

However, the new global world displaces the ecological perspective and puts anthropogenic perspective, the dark heritage of Enlightenment, in the center. 
80 Even though the ecological benefits of COVID-19 are mentioned, it is possible to say that I paradigm is dominant instead of We paradigm in digital environment. For this reason, the hyper-individualized people try to save themselves and think about how their actions will derive a profit instead of reaching the common good by acting together. As Beck emphasizes, "as the risk society develops, so does the antagonism between those afflicted by risks and those who profit from them" (Beck, 1986: 46).

\section{INSTRUMENTALISM OF FEAR THROUGH INFODEMIC}

A recent academic work over COVID-19 outbreak says that the current law does not satisfy the fast-changing social demands and needs to be changed at least for this time period (Johnson and Bailey, 2020). In the extraordinary situation we experience, is it possible that hegemon ones become a state of exception without being out of law? The Agamben statement made in the first days of the COVID-19 crises in Italy has received heavy criticism. He says that people — putting aside their sociality, emotions, religious and political views - started to believe in bared-life because of the wave of panic (Agamben, 2020). At this point, can "the state of exception" — which had been conceptualized in the 20th century- be globalized in the 21 st century ${ }^{20}$ Of course, many centuries might need to pass a hundred years in order to directly see this case as the great incarceration of Foucault but moreover, Agamben's concern is the future, much more than the present. At this point, it is useful to remember Bauman's thought that humanity swings like a pendulum between the security and freedom dilemma from past to the future. As a matter of fact, it is important to ask this question: if our social relations get disturbed because of this global crisis, what would the individual or the society, which has no value rather than just living, would look like? If the freedom-security scales weight more on the security side, the society can support the populist and hegemonic thoughts by increasing the level of apprehension. The human kind works on staying alive and protecting themselves when the environment becomes dangerous. In this case, regarding Freudian aspect, the survival of humankind under the global crisis environment is directly proportional with their adaptation capacity. According to Freud, human behaviour is determined, not accidental. Unlikely, they harmonize with the environment by increasing the anxiety level in order to survive when necessary (Freud, 1920). The human that became tied up to the authority as a result of even the threats becoming global and the increasing of the risk intensity, is forced to only obey the rules for the solution of the problem. This kind of huge threats can be eliminated by the modern institutions - they stop the terrorist attacks,

20 At this point, Agamben is criticized by many thinkers. For example, Roberto Esposito (2020) says that today's events should not be compared to the great tragic events of the past. According to him, quarantine at home and the maximum security prisons are not the same. 
find the antidote of the virus and develop vaccine-. The information flow of all these progresses is provided by the media. Together with the development of technology, even though the exponential increase of information flow with the liberal statement commits to individuals the freedom of expression, information pollution is a big problem today. This problem is the dominant fact that changes the quality and quantity of communication technologies in the human channel.

Before COVID-19 was declared a pandemic by the WHO, the news going around through social media about the virus appeared in China were not necessary for people to understand how an outbreak they face. People's hunger for reality is an important fact that increases the social anxiety level of the global crisis. The essential bias of the reliability of scientific information has appeared in this process and has pushed the people to caricature their fears. The countries fighting the coronavirus, as there were statements claiming this outbreak was a highly vital threat from the institutions and individuals who had different qualities and titles; there also appeared statements claiming the outbreak is not vital threat and will be gone in a short while. This case caused a mental complexity in individuals and societies; laid the ground for the lack of productivity in the way of putting precautions by the states. ${ }^{21}$ Because of the overabundance of information on the virus, people are having troubles reaching the trustworthy information. When Twitter is examined as an example, it is seen that there are hashtags like \#covid19, \#coronavirüs, \#koronavirüs, \#wuhanvirüsü used in more than 4 billion posts and 100 billion interactions. Similarly, since the first COVID-19 case, news about the outbreak such as numbers of cases, numbers of deaths, Ministry of Health statements, prohibitions, lockdowns, vaccine research etc. have been produced in the traditional media - every evening in the main news bulletins and newspapers- - In this case, it can be stated that this crisis we've been through in is a communication crisis rather than pandemic. ${ }^{22}$ As stated before, humankind is capable of adapting to its environment s/he belonged. In this case, the anxiety level that is increased by the fear of being carrier or infected directly affects the practice of communication between the people. The global crisis which is experienced like this, is not a case to be explained with "stay at home" situations.

Facts setting off each other as uncertainty, lacking communication, increasing social and physical distance, decreasing mobility causes the instability of fear and apprehension for the people. It can be expected from the individual to be neurotic and over reactional in this kind of an environment. It is inevitable that hyper-rationalism and "the new the state of exception" Agamben's put emphasis will take the people to a post-emotional society.

$21<$ <ttps://www.aa.com.tr/tr/analiz/koronavirus-salgini-risk-toplumu-ve-sosyo-psikolojik-sonuclari/1784788>.

22 Leach et al. (2020) describes COVID-19 as a social phenomenon: "As the COVID-19 pandemic rages across the world, one thing is clear: this epidemic, like all others, is a social phenomenon". 
"Postemotional control is aimed at the emotions, not the mind. The power of rationality and of the mind enshrined by the Enlightenment has given way to an indolent mindlessness" (Mestrovic, 1997: 15). Also it is possible that the new exceptional situation takes people to a highly safe world. Like Frank Furedi stated, "the celebration of safety alongside the continuous warning about risks constitutes a profoundly anti-human intellectual and ideological regime. It continually invites society and its individual members to constrain their aspirations and to limit their actions. The call for restraint can now be heard everywhere, be it in discussions on science, school results or living standards. Such continuous lowering of expectations can be justified through an exaggerated presentation of the destructive side of science, or through the projection of people as fragile individuals who cannot be expected to cope" (Furedi, 2002: 13). Following coronavirus cases via mobile phones which is claimed to be done in China and Israel can normalize the individuals living in the high surveillance society. ${ }^{23}$ In this case, we can understand the process of leading to the high surveillance society by Elisabeth Kübler-Ross's five phase schema: denial, anger, bargaining, depression and acceptance (Kübler-Ross, Wessler, and Avioli, 1972: 179).

Outbreaks like black plague, Spanish flu etc. were the crisis that societies have experienced. But today, what separates COVID-19 from the other outbreaks is the fact that this pandemic is described as a safety problem (Hameiri and Jones, 2015). At first, by the populist leaders and some scientists, this safety problem was claimed as not being a big crisis. Also, some conspiracy theories that appeared by the unintellectualizing of people had supported these ideas. For now, there is social anger towards the hardline politics implemented by the state authorities. Especially in Turkey, action by the government contrary to welfare state concepts, such as making unpaid leaves legal for companies, causes explosions of anger by those who cannot obey the \#stayathome call because of the economic situation.

Populist politicians - as if they want the conservative society be thankful for what they have been through — make the mosques say salawat after call to prayer therefore, forcing ideologically the under-risk individuals to obey their destinies. For now, the situation in Turkey seems like anger but, are we going to be able to bargain when we are asked to download applications to our mobile phones in order to be under controlled like in China and Israel? Time will show that.

\section{CONCLUSION}

There are some breakpoints of the world history and they change the flow of history in the aspect of economy, law, politics and the social results. The rela-

$23<$ https://www.theguardian.com/world/2020/mar/17/israel-to-track-mobile-phonesof-suspected-coronavirus-cases>; <https://www.nytimes.com/2020/03/01/business/china-coronavirus-surveillance.html>. 
tionship between today's global crisis and social life will create breakpoints of the epistemology of communication. Like it is pointed out in the worldwide researches and works, instrumental communication has taken over the conventional communication especially in social media and this is the new principal of the modern statement. The negativity that the concretion of individualism and being virtual have created the problems in the transition period between the old and new. The transition period we've been through today shows that these problems will be painful. The anxiety intensity that caused by the individuals feeling at risk about health and economy evolves into miscommunication with the nearest environment and social mistrust. The panic environment in the fear culture can speed up the production of statements that can destroy the social unity. The isolation of the individual by her/himself — for her/his safety - and by the state authority, forces to change her/his consciousness and perception. Even if this seems like a pessimist picture, the irrational society can take their social choices to solidarity statements rather than isolation. In this case; the times in which the social exclusion, hate speech and fear culture have been spread, the people need to take the COVID-19 crises as a social phenomenon. Only by getting this kind of awareness will make the new social and cultural relationships appear and, strengthen the social solidarity and collectivity.

Ugur Baloglu (ubaloglu@gelisim.edu.tr) is an assistant professor in the School of Applied Sciences at Istanbul Gelisim University. He received his $B$. Ed. from Marmara University and BA from Maltepe University. He completed his MA in 2012 in the field of
Communication Design at Istanbul Kultur University. He completed his PhD in Radio Television Cinema at Istanbul University in 2017. His research interests include media and cultural studies, gender and sociology of communication.

\section{References}

Agamben, G. (2020). "L'invenzione di un'epidemia". Quodlibet. Available at: <https://www.quodlibet.it/giorgio-agambenl-invenzione-di-un-epidemia>. Accessed 10 March 2020.

Ahiska, M. (2003). "Occidentalism: The Historical Fantasy of the Modern". The South Atlantic Quarterly, 102(2), pp. 351-379.

Ahmad, F. (1993). The Making of Modern Turkey. Vol. 264. London: Routledge.
Beck, U. (1986). Risk Society: Towards a New Modernity. Trans. M. Ritter. London: Sage Publications.

-. (2005). The Reinvention of Politics: Rethinking Modernity in the Global Social Order. Trans. M. Ritter. Cambridge: Polity Press.

Berman, M. (1988). All That Is Solid Melts into Air. New York: Penguin Books.

Butler, J. (2020). "Capitalism Has Its Limits". Verso. Available at: <https://www.versobooks. 
com/blogs/4603-capitalism-has-its-limits>. Accessed 4 April 2020.

Cinelli, M.; Quattrociocchi, W.; Galeazzi, A.; Valensise, C. M.; Brugnoli, E.; Schmidt, A. L.; Zola, P.; Zollo, F., and Scala, A. (2020) "The COVID-19 Social Media Infodemic". arXiv preprint arXiv:2003.05004. Available at: <https:// arxiv.org/abs/2003.05004>. Accessed 10 April 2020.

Dijk, T. A. van (1988). News Analysis. Case Studies of International and National News in the Press. New Jersey: Lawrence.

—. (1990). "Social Cognition and Discourse". In: Giles, H. and Robinson, W. P. (eds.). Handbook of Language and Social Psychology. New Jersey: Wiley, pp. 163-183.

Ehrenreich, B. (1989). Fear of Falling: The Inner Life of the Middle Class. New York: Pantheon Books.

Ergin, F.; Evci-Kiraz, E. D.; Saruhan, G.; Benli, C.; Okyay, P., and Beser, E. (2012). "Prevalence and Risk Factors of Elder Abuse and Neglect in a Western City of Turkey: A Community Based Study". Bulletin of the Transilvania University of Brasov. Medical Sciences. Series VI, 5(2).

Esposito, R. (2020). "Curati a oltranza". Antinomie. Available at: <https://antinomie. it/index.php/2020/02/28/curati-a-oltranza>. Accessed 10 March 2020.

Foucault, M. (2011). Büyük Kapatılma, Trans. Iş1k Ergüden and Ferda Keskin. İstanbul: Ayrıntı.

Freud, S. (1920). A General Introduction to Psychoanalysis. California: Createspace.

Fuchs, C. (2008). Internet and Society: Social Theory in the Information Age. New York: Routledge.

Furedi, F. (2002). Culture of Fear Revisited: Risk-taking and the Morality of Low Expectation. London: Continuum.

Giddens, A. (1990). The Consequences of Modernity Polity. Cambridge: Polity Press.

Günal, Y. (2013). Neoliberal Transformation and Professional Middle Classes: Case of Engineers in Turkey. PhD Dissertation. Middle East Technical University. Available at: <http://etd. lib.metu.edu.tr/upload/12616180/index.pdf>. Accessed 12 April 2020.

Hameiri, S. and Jones, L. (2015). "Governing Infectious Disease: H5N1 Avian Influenza in Southeast Asia". In: Governing Borderless Threats: Non-Traditional Security and the Politics of State Transformation, pp. 124-159. Cambridge: Cambridge University Press.

Honneth, A. (2004). "Organized Self-Realization: Some Paradoxes of Individualization". European Journal of Social Theory, 7(4), pp. 463478.

Jarrar, Y.; Awobamise, A.; Nnabuife, S., and Nweke, G. E. (2020). "Perception of Pranks on Social Media: Clout-Lighting". Online Journal of Communication and Media Technologies, 10(1).

Jenkins, H. (2003). "Interactive Audiences?". In: Nightingale, V. and Ross, K. (eds.). Critical Reading: Media and Audiences. London: Open University Press, pp. 279-297.

Johnson, E. and Bailey, Th. C. (2020). "Urgent Legal Lessons from a Very Fast Problem: COVID-19". Stanford Law Review Online. Forthcoming.

Kouzy, R.; Abi-Jaoude, J.; Kraitem, A.; ElAlam, M. B.; Karam, B.; Adib, E.; Zarka, J.; Traboulsi, C.; Akl, E. W., and Baddour, K. (2020). "Coronavirus Goes Viral: Quantifying the COVID-19 Misinformation Epidemic on Twitter". Cureus, 12(3).

Kübler-Ross, E.; Wessler, S., and Avioli, L. V. (1972). "On Death and Dying". Jama, 221(2), pp. 174-179.

Leach, M.; Parker, M.; MacGregor, H., and Wilkinson, A. (2020). "COVID-19 - A Social Phenomenon Requiring Diverse Expertise". Institute of Development Studies. Available at: $<$ https://www.ids.ac.uk/opinions/covid-19-asocial-phenomenon-requiring-diverseexpertise/>. Accessed 14 April 2020.

Lyotard, J. F. (1979). La condition postmoderne [The postmodern condition]. Paris: Minuit.

Manovich, L. (2002). The Language of New Media. Massachusetts: MIT Press.

Mestrovic, S. (1997). Postemotional Society. London: Sage Publications Ltd. 
Patton, D. U.; Hong, J.; Ranney, M.; Patel, S.; Kelley, C.; Eschmann, R., and Washington, T. (2014). "Social Media As a Vector for Youth Violence: A Review of the Literature". Computers in Human Behavior, 35, pp. 548-553.

Postman, N. (2005). Amusing Ourselves to Death: Public Discourse in the Age of Show Business. New York: Penguin.

Recommendation, N. O. "R (97) 20 Of the Committee of Ministers to Member States on 'Hate Speech'”. Available at: <https:// search.coe.int/cm/Pages/result_details.aspx? ObjectID $=0900001680505 \mathrm{~d} 5 \mathrm{~b}>$. Accessed 10 April 2020.

Schild, L.; Bansal, S.; Bode, L.; Budak, C.; Chi, G.; Kawintiranon, K.; Padden, C.; Vanarsdall, R.; Vraga, E., and Wang, Y. (2020). “"Go Eat a Bat, Chang!": An Early Look on the Emergence of Sinophobic Behavior on Web Communities in the Face of COVID-19". arXiv preprint arXiv:2004.04046. Available at: $<$ https://arxiv.org/abs/2003.13907>. Accessed 10 April 2020.

Shaw, S. and Shaw, E. (1977). History of the Ottoman Empire and Modern Turkey. Cambridge: Cambridge University Press.

Silver, H. (1994). "Social Exclusion and Social Solidarity: Three Paradigms". International Labour Review, 133 (5-6), pp. 531-578.
Singh, L.; Bansal, S.; Bode, L.; Budak, C.; Chi, G.; Kawintiranon, K.; Padden, C.; Vanarsdall, R.; Vraga, E., and Wang, Y. (2020). "A First Look at COVID-19 Information and Misinformation Sharing on Twitter". arXiv preprint arX$i v: 2003.13907$. Available at: <https://arxiv.org/ abs/2003.13907>. Accessed 10 April 2020.

Stirling, P. (1953). "Social Ranking in a Turkish Village". The British Journal of Sociology, 4(1), pp. 31-44.

Sunstein, C. (2007). Republic.com 2.0. New Jersey: Princeton University Press.

Thaler, R. H. and Sunstein, C. R. (2009). Nudge: Improving Decisions about Health, Wealth, and Happiness. New York: Penguin.

Turkish Statistical Institute. (2010). “Urban and Rural Population, 1927-2000". Available at: <http://www.tuik.gov.tr/PreIstatistikTablo. do?istab_id=202>. Accessed 7 June 2020.

Weber, A. (2009). Manual on Hate Speech. Strasbourg: Council Of Europe Publishing.

Young, J. (2007). The Vertigo of Late Modernity. London: Sage.

Zizek, S. (2020). "Monitor and Punish? Yes, Please!". The Philosophical Salon. Available at: $<$ https://thephilosophicalsalon.com/monitorand-punish-yes-please>. Accessed 7 April 2020 . 
